\title{
New Products Based on Essential Oils for the Treatment of Medical Furs
}

\author{
OLGA NICULESCU*, LUMINITA ALBU ${ }^{1}$, MARIA CARMEN LOGHIN², CARMEN GAIDAU ${ }^{1}$, LUCRETIA MIU1', GHEORGHE COARA ${ }^{1}$ \\ ${ }^{1}$ National Research and Development Institute for Textiles and Leather - Division Leather and Footwear Research Institute, 93 \\ Ion Minulescu Str., Bucharest, Romania \\ ${ }^{2}$ Gheorghe Asachi Technical University of Iasi, Faculty of Textile - Leather and Industrial Management, 28 Dimitrie Mangeron \\ Str., lasi, Romania
}

\begin{abstract}
Sheep furskins for medical use were tanned with non-metallic tanning materials (syntans based on phenolsulphonic acids and aromatic oxysulfones). Sanitation of medical furs was made using essential oils, with therapeutic effect, in the final treatment of tanned furs. The paper refers to obtaining and physicalchemical characterization of new products based on natural oils (eucalyptus essential oil), ethyl alcohol, non-ionogenic surfactants from the category of polyethoxylated fatty alcohols and polyethylene glycols and water, for the treatment of medical furs. Eucalyptus essential oil used to obtain new products was analysed using GC-MS and spectral analyses. The furs will be used to make natural fur articles for medical purposes (lumbar belts, knee pads, elbow pads etc.) to relieve rheumatic and muscular pain of the affected target areas, keeping the area warm and potentiating the medical treatment of the patients who suffer from these conditions.
\end{abstract}

Keywords: ecological furs for medical use, eucalyptus essential oil, quality, FT-IR spectrometry, Gas Chromatography Mass Spectrometry (GC/MS), UV-Vis spectrometry

In recent years, significant progress has been made in developing the hygienic potential of natural fur.

Ecological requirements as well as requirements related to fur assortment characteristics have led to the development of new fur processing technologies, such as:

- wet-white tanning of fur to eliminate or reduce the amount of complex salts of trivalent chromium;

- tanning using chemically modified vegetable tannins or small molecular phenolic and polyphenolic compounds, including those derived from cellulose-making and refining techniques;

- sanitation of natural fur by binding some therapeutic species to the dermis and/or the hair [1, 2].

There are a number of people with rheumatic, joint and muscular diseases and medical treatment of patients suffering from these diseases requires improvement through alternate methods.

Rheumatism is a condition located in the musculoskeletal system and in the heart area, as a result of inflammatory or degenerative injuries of connective tissue. Rheumatic pains are predominantly located in the joints. Treating rheumatic diseases is practiced by oral administration of drugs and the application of cataplasms, gels, ointments, creams, patches with analgesic effect. Pain is the main symptom of rheumatic diseases. Chronic pain affects the physical and mental condition and thus lowers the quality of life and ability to work. For these diseases are recommended herbal plant species with antiallergic, anti-inflammatory effects, etc. Heat can relieve rheumatic pains (transmitted through the application of natural fur).Many species of plants containing essential oils bring their contribution all over the world in preventing various diseases. Eucalyptus (Eucalyptus globulus $L$ ) is part of the Myrtaceae family and is a tree with evergreen leaves, specific to Australian flora. Essential oil is obtained by steam distillation of young leaves and branches [3-18].
This paper presents characterization of the eucalyptus essential oil by gas chromatography coupled with mass spectroscopy - GC-MS and, FT-IR and UV-Vis spectrometry, $[19,20]$ and the process of obtaining and physical-chemical characterization of new products based on eucalyptus essential oil, ethyl alcohol, non-ionogenic surfactants from the category of polyethoxylated fatty alcohols and polyethylene glycols, and cationic surfactants (quaternary ammonium salts), for the treatment of medical furs.

Dense and fine wool sheepskins (Merinos) were selected to obtain finished products coated with fine and dense hair follicles.

Sheepskins were tanned (non-metallic tanning) with syntans based on phenolsulphonic acids and aromatic oxisulfones, [21-23] and in the final finishing phase were treated with products based on essential oils with therapeutic properties (analgesic, anti-inflammatory and relaxing).

\section{Experimental part}

Materials and methods

- Eucalyptus oil (Adams, Romania), containing 73.23\% eucaliptol, $14.99 \%$ limonene, $4.10 \%$ 0-cymene, $2.82 \%$ gama-terpinene etc.;

- Ethanol (Chemical Company, Germany), colorless liquid, boiling point $78.37^{\circ} \mathrm{C}$, density $-0.79 \mathrm{~g} / \mathrm{cm}^{3}$;

- Nonionic emulsifier - lauryl alcohol ethoxylated with 7 moles of ethylene oxide (Elton Corporation, Romania), density - $0.95 \mathrm{~g} / \mathrm{cm}^{3}$ at $40^{\circ} \mathrm{C}, \mathrm{pH}$ (10\% solution) - 7-8;

- Polyethylene Glycol 400 (Merck, Germany), density $1.13 \mathrm{~g} / \mathrm{cm}^{3}$ at $20^{\circ} \mathrm{C}$, flash point > $200^{\circ} \mathrm{C} ; \mathrm{pH}(10 \%$ solution) 5-7; melting point $-5^{\circ} \mathrm{C}$, ignition temperature $-360^{\circ} \mathrm{C}$;

- Hexadecyl-trimethyl ammonium bromide (Merck, Germany), water solubility of 3g/L, $\mathrm{pH}$ ( $10 \%$ solution) $-5-7$, melting point $237-243^{\circ} \mathrm{C}$, hygroscopic; 
- Product made from eucalyptus essential oil: dry substance - $17-18 \%$, pH (10\% solution) - 4-4.5, density 0.880-0.890 $\mathrm{g} / \mathrm{cm}^{3}$;

- Sheepskins tanned with syntans syntans (Triderma SRL, Romania), based on phenolsulphonic acids and aromatic oxisulfones (National Research and Development Institute for Textiles and Leather - Division Leather and Footwear Research Institute Bucharest, Romania).

Synthesis of materials based on plant extracts was conducted in a glass flask using a heating and homogenization installation (Velp) and an ultrasonic bath (Elmasonic S 15 H).

Attenuated Total Reflectance Fourier transform infrared spectroscopy (ATR-FTIR) measurements were run with a Jasco instrument (model 4200), in the following conditions: wavenumber range - $600-4000 \mathrm{~cm}^{-1}$; data pitch -0.964233 $\mathrm{cm}^{-1}$; data points - 3610: aperture setting - $7.1 \mathrm{~mm}$; scanning speed $-2 \mathrm{~mm} / \mathrm{s}$; number of scans - 30; resolution $-4 \mathrm{~cm}^{-1}$; filter - $30 \mathrm{kHz}$; angle of incident radiation - $45^{\circ}$.

Gas Chromatography Mass Spectrometry (GC/MS) Analysis:

Analysis of the essential oils was carried out by using Agilent 7890 A GC System equipped with Agilent 5795 C MS, and HP-5 MS $(0.25 \mathrm{~mm} \times 30 \mathrm{~m}$ i.d., film thickness $0.25)$. The carried gas helium $(99.9 \%)$ at a flow rate of 1 $\mathrm{mL} / \mathrm{min}$; ionization energy was $70 \mathrm{eV}$. Mass range $\mathrm{m} / \mathrm{z} 50$ 650 amu. Data acquisition was scan mode. MS transfer line temperature was $250^{\circ} \mathrm{C}$, MS Ionization source temperature was $230^{\circ} \mathrm{C}$, the injection port temperature was $250^{\circ} \mathrm{C}$. The samples were injected with 250 split ratio. The injection volume was $1 \mu \mathrm{L}$. Oven temperature was programmed in the range of 50 to $250^{\circ} \mathrm{C}$ at $3^{\circ} \mathrm{C} / \mathrm{min}$. The structure of each compound was identified by comparison with their mass spectrum (Nist 05 and Wiley 7 library).

A UV-Vis spectrophotometer model JASCO, V-550, equipped with $1 \mathrm{~cm}^{3}$ quart cuvettes, was used in this paper and absorbance was measured on the 200-800 nm range. To identify the phenol from UV-VIS fingerprintspectras for two extracts of cloves and eucalyptus, a dilution was made for the both extracts: $0.1 \mathrm{~mL}$ of extract $+10 \mathrm{~mL}$ of ethanol. Sheepskins were tanned and treated with products based on essential oils with therapeutic properties in rotating barrels FA.VE (Italy).

Obtaining product based on eucalyptus essential oil

The following components were added to the mixing vessel: $55-65 \%$ eucalyptus essential oil, $10-12 \%$ ethyl alcohol, 8-10\% lauric alcohol ethoxylate with seven moles of ethylene oxide, 8-10\% polyethylene glycol 400 (nonionogenic), $1 \%$ hexadecyltrimethylammonium bromide (cationic) and deionized water. Components were homogenised using a mechanical stirrer, on an electrically heated installation, at the temperature of $30-35^{\circ} \mathrm{C}$, for 15 $20 \mathrm{~min}$. In order to homogenise components, an ultrasound bath was used, in which the glass flask was inserted, at the temperature of $25^{\circ} \mathrm{C}$, for $10 \mathrm{~min}$. [24-27].

The product obtained was marked P-EUC.

\section{Obtaining ecologic medical sheepskins}

Ecologic medical sheepskins were obtained using the products [23] based on sulphated fatty alcohols (Borron SAF), oils based on sulphated and sulphonated natural and synthetic fatty substances (Coripol UFB/W) and syntans based on phenol sulphonic acids and aromatic oxysulphones (Sellatan MBS, Sellatan RL), according to the technology in table 1.

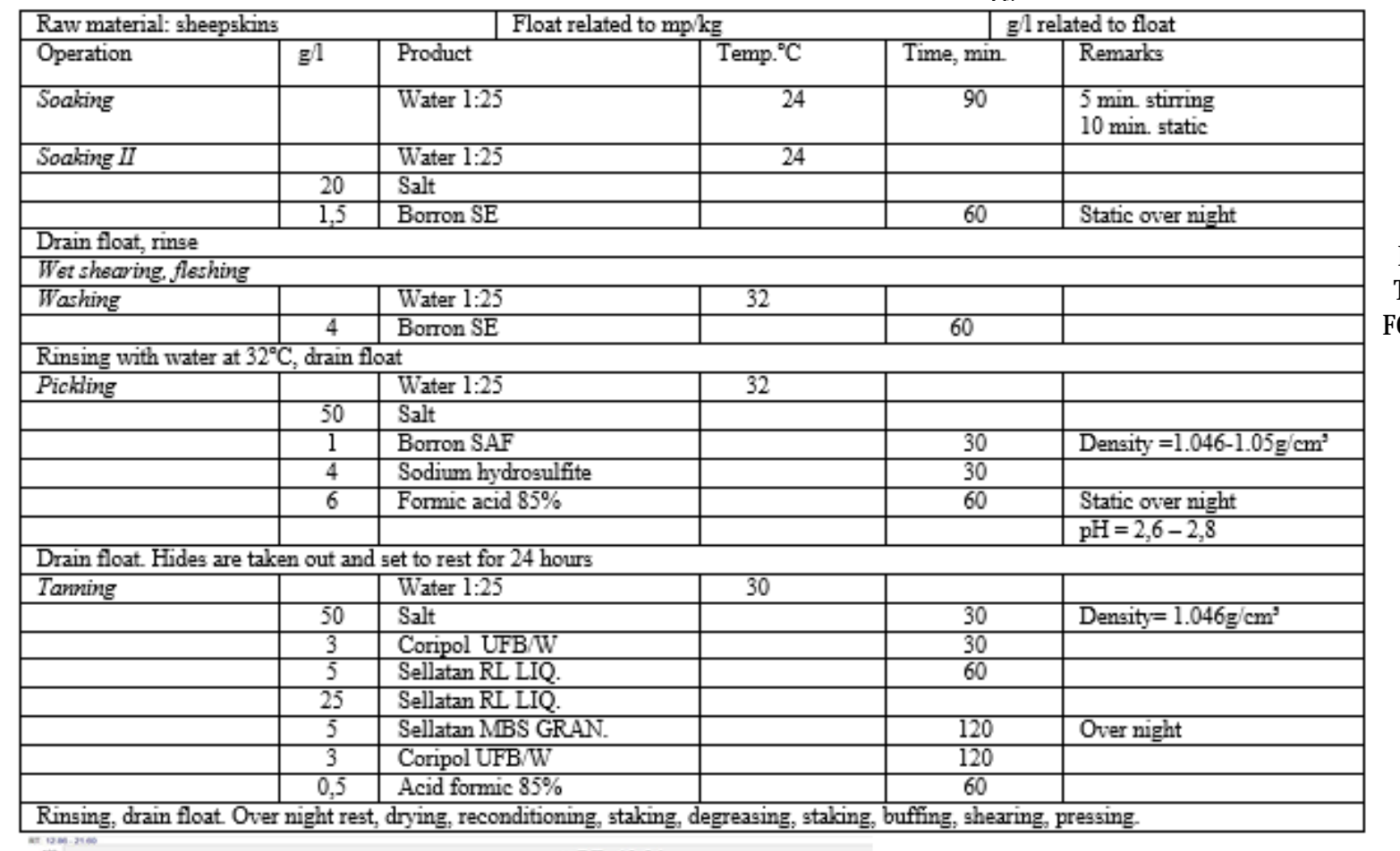

Table 1 FRAMEW ORK TECHNOLOGY FOR OBTAINING ECOLOGIC MEDICAL SHEEPSKINS
Fig.1. Chromatogram of organic compounds in the eucalyptus oil

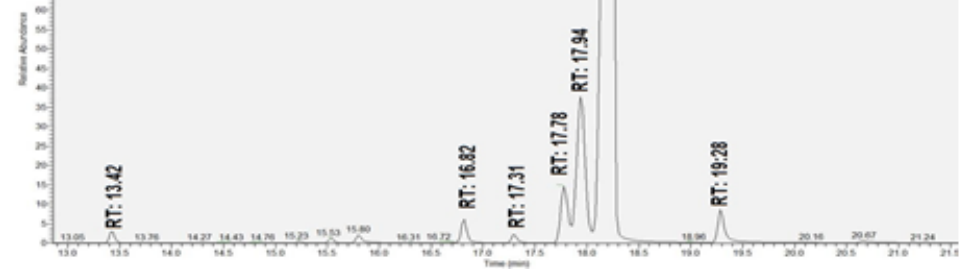




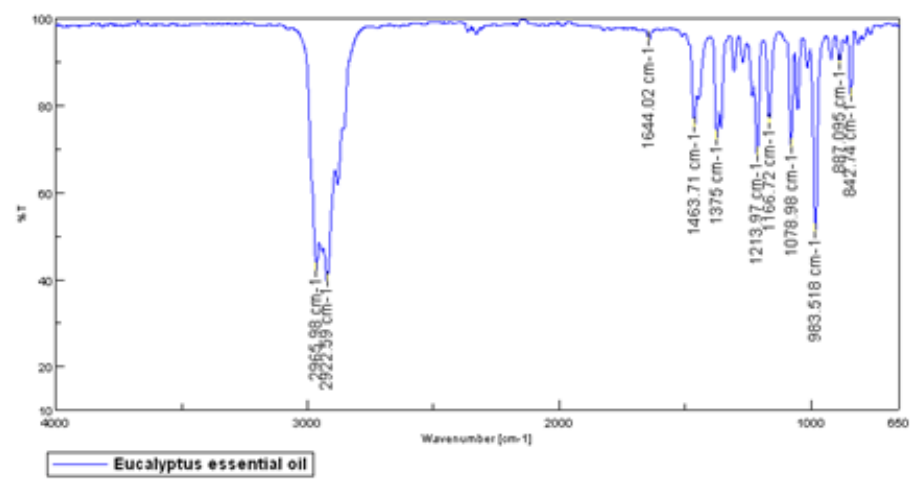

Fig. 2. FT-IR spectra of eucalyptus essential oil

\section{Results and discussions}

Characterisation of components used to obtain the product

Eucalyptus essential oil used to obtain the product was analysed using GC-MS and FT-IR. Chromatogram for eucalyptus oil is shown in figure 1 , and identification of compounds in its composition is presented in table 2.

The following compounds are found in the highest amount: eucaliptol - $73.23 \%$, d-limonene - $14.99 \%$, ocymene $-4.10 \%$ and gama-terpinene $-2.82 \%$. The major components were: 1,8-Cineole (eucalyptol) and dLimonene. The quality of Eucalyptus globulus product meets the standard (ISO 770:2002. Crude or rectified oils of Eucalyptus globulus Labbil.) if content of 1,8-Cineole is not less than $70 \%$.

FT-IR (ATR) spectra of eucalyptus essential oil are shown in figure 2.

Thes bicyclocamphane compound can be identified by the most intensive band at $983 \mathrm{~cm}^{-1}$. Other characteristic bands of 1,8-Cineole, which are seen in the FTIR spectrum, can be attributed to C-O-C symmetrical $\left(1079 \mathrm{~cm}^{-1}\right)$ and asymmetrical $\left(1214 \mathrm{~cm}^{-1}\right)$ stretching vibrations as well as to $\mathrm{CH}_{3}$ symmetrical deformation modes recognised at 1375 $\mathrm{cm}^{-1}$.

UV-Vis spectra of eucalyptus essential oil are shown in figure 3 .

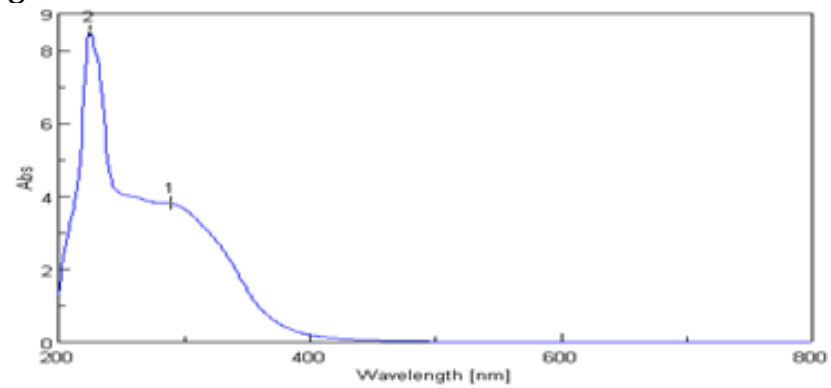

Fig. 3. UV-Vis spectra of eucalyptus essential oi

The sample of eucalyptus oil extract was analyzed by the UV-Vis spectroscopy method.

UV-Vis spectra of oil sample in ethanol show the presence of tannins, because the absorption peak observed at 200-280 nm is typical for condensed benzene ring system, in which conjugation is realized between aromatic group and carbonyl group, double bond or hetero atom.

\section{Physical-chemical characteristics of product based on eucalyptus oil}

The prepared product, P-EUC, is yellowish white fluid, homogenous, with $17-18 \%$ dry substance, $\mathrm{pH}-4.0-4.5$, density $-0.880-0.890 \mathrm{~g} / \mathrm{cm}^{3}$.

Chemical characteristics of productbased on eucalyptus oil were determined according to the following standards: dry substance (\%) -SR EN ISO 4684:2006; pH - SR-EN ISO 4098: 2006.
Table 2

IDENTIFICATION OF ORGANIC COMPOUNDS IN THE EUCALYPTUS ESSENTIAL OIL BY GC-MS

\begin{tabular}{|c|c|c|c|}
\hline No. & RT & Amount, \% & Compounds \\
\hline 1 & 13.42 & 0.1 & alpha-pinene \\
\hline 2 & 15.23 & 0.13 & alpha-phellandrene \\
\hline 3 & 15.53 & 0.36 & 2-alpha-pinene \\
\hline 4 & 15.8 & 0.71 & alpha-myrcene \\
\hline 5 & 16.82 & 1.96 & 1-phellandrene \\
\hline 6 & 17.31 & 0.79 & alpha-terpinene \\
\hline 7 & 17.78 & 4.10 & O-cymene \\
\hline 8 & 17.94 & 14.99 & D-Limonene \\
\hline 9 & 18.24 & 73.23 & Eucalyptol \\
\hline 10 & 19.28 & 2.82 & gama-terpinene \\
\hline
\end{tabular}

Characterization by physical-chemical and physicalmechanical analyses of furs

The values of the physical-chemical characteristics of the medical furs are comparable to the values set by the standards for sheep furskins intended for clothing (volatile dermal matter 11.16-11.66\% and volatile wool matter 9.82$12.21 \%$, extractable dermal substances $9.31-11.21 \%$ and wool extracts $0.41-0.78 \%$, ash $3,02-3,63 \%$, pH of aqueous extract, 4.

Values of shrinkage temperatures for medical sheep furskins are lower $\left(73^{\circ} \mathrm{C}\right)$ than those of sheep furs processed with basic chromium salts (approx. $80^{\circ} \mathrm{C}$ ).

The following were determined Chromium VI content undetectable values.

The longitudinal tensile strength tests resulted in a value of 216-341 N, compared to the standard for the tanned sheep furskins with chromium salts for clothing, which are of min. $110 \mathrm{~N}$, and the transverse tensile strength values are 194-231 N, compared to the values given in the standard for sheep furskins tanned with chromium salts for clothing, which are of min. $80 \mathrm{~N}$.

Chemical and mechanical characteristics of furs were determined according to the following standards: volatile matter \% -SR EN ISO 4684:2012, extractable substances $\%$-SR EN ISO 4048:2002, ash \% - SR EN ISO 4047:2002, shrinkage temperatures $\left({ }^{\circ} \mathrm{C}\right)$ - SR EN ISO 3380:2003, the longitudinal and transverse tensile strength -SR EN ISO 3376:2012.

\section{Characterisation of furs assortments obtained}

Product preparations - P-EUC - contain 55-65\% eucalyptus essential oil, 10-12\% ethyl alcohol, 8-10\%lauric alcohol ethoxylate with seven moles of ethylene oxide, 8$10 \%$ polyethylene glycol 400 (non-ionogenic), $1 \%$ hexadecyltrimethylammonium bromide (cationic) and deionized water.

The obtained products can be applied to Merinos sheep fur in two ways:

- in the float as a final operation using 20-30\% essential oil based products in $100 \%$ water bath at $50-60^{\circ} \mathrm{C}$ in the presence of a biodegradable nonionic emulsifier, ethoxylated lauryl alcohol with 7 moles of ethylene oxide ( $10 \%$ of the amount of product used) for $30 \mathrm{~min}$.

- by dabbing with a cloth on the fur or fur articles.

Treatment with these products can be repeated at certain time intervals, and the application procedure on the fur surface or fur articles is easy.

The products can be used to treat the surface of finished sheep furskins (free of metals) for medical purposes and improve the quality of natural fur and fur articles (lumbar belts, knee pads, elbow pads etc.) used to prevent, relieve 
and treat rheumatic, muscular, circulatory disorders, complementing the medical treatment of patients suffering from these conditions, keeping the fur-covered area warm.

\section{Conclusions}

The prepared product, P-EUC, is yellowish white fluid, homogenous, with $17-18 \%$ dry substance, $\mathrm{pH}-4.0-4.5$, density $-0.880-0.890 \mathrm{~g} / \mathrm{cm}^{3}$.

The P-EUC product with therapeutic properties (analgesic, anti-inflammatory and relaxing) can be used (in proportion of 20-30\%) for treatment of medical furs.

Sheepskins were tanned with syntans based on phenolsulphonic acids and aromatic oxisulfones.

The products can be used to treat the surface of finished sheep furskins ( free of metals) for medical purposes and improve the quality of natural fur and fur articles (lumbar belts, knee pads, elbow pads etc.) used to prevent, relieve and treat rheumatic, muscular, circulatory disorders, complementing the medical treatment of patients suffering from these conditions, keeping the fur-covered area warm.

Acknowledgment: This article is funded by the Ministry of Research and Innovation within Program 1 - Development of the national RD system, Subprogram 1.2 - Institutional Performance - RDI excellence funding projects, Contract no. 6PFE/ 16.10.2018.

\section{References}

1. CHIRITA, Gh., CHIRITA, M., Tratat de chimia si tehnologia pieilor si blanurilor, I, Ed. Gh. Asachi, laoi 1999.

2. MAIER,S.S., Tehnologia prelucrãrii blãnurilor. Note de curs. Universitatea Tehnica Gh. Asachi din lasi, 2008.

3. *** Farmacopeea Romana, edipa a X-a, Ed. Medicala, Bucuresti, 1998.

4. *** European Pharmacopeia, vol. II, ESCOP Strasbourg, Council of Europe, 2005.

5. CIULEI, I., GRIGORESCU, E., STANESCU, U., Plante medicinale, fitochimie si fitoterapie, vol. 2, Ed. Medicala, Bucuresti, 1993.

6. PALADE, M., Botanica farmaceuticã, Ed. Tehnica, Bucuresti, 1998. 7. PARVU, C., Enciclopedia plantelor. Plante din flora Romaniei, Bucure-ti, Editura Tehnica, 2002.

8. CONSTANTINESCU, D.G., HATIEGANU, E., BUSURICU, F., Plante medicinale utilizate în terapeutica, Bucuresti, Editura Medicala, 2004. 9. STANESCU, U., MIRON, A., HANCIANU, M., APROTOSOAIE, C., Plante medicinale de la A la Z, lasi , Editura Gr. T. Popa, 2004.

10. ARDELEAN, A., MOHAN, G., Flora medicinala a Romaniei, Bucuresti, Editura All, 2008.

11. ISTUDOR, V., Farmacognozie, Fitochimie, Fitoterapie, vol. I, Ed. Medicala, Bucuresti, 1998.

12. MOLERIU, L., JIANU, C., BUJ ANCA, G., DOROS, G., MISCA, C., ILIE, O.C., MOLERIU, R.D., ILIE, A.C., Essential Oil of Hypericum perforatum. The chemical composition and antimicrobial activity, Rev. Chim. (Bucharest), 68, no. 4, 2017, p.687.
13. TOMA, C.C., CASACCHIA, T., D'IPPOLITO, C., STATTI, G., Ficus carica SPP Dottato Buds by Intercropping Different Species: Metabolites, Antioxidant Activity and Endogenous Plant Hormones (IAA, ABA), Rev. Chim. (Bucharest), 68, no. 7, 2017, p.1628.

14. TOMA, C.C., CASACCHIA, T., DON, I., D'IPPOLITO, C., STATTI, G., New Extraction Technologies for Syringa Vulgaris (Oleaceae) Meristematic Extracts, Rev. Chim. (Bucharest), 68, no. 8, 2017, p. 1796.

15. LISA, E.C., CARAC, G., BARBU, V., ROBU, S., The Synergystic Antioxidant Effect and Antimicrobial Efficacity of Propolis, Myrrh and Chlorhexidine as Beneficial Toothpaste Components, Rev. Chim. (Bucharest), 68, no. 9, 2017, p.2060.

16. JURCA, T., MARIAN, E., TITA, B., VICAS, S., PALLAG, AM.,TOTH, I., KRUSPER, L., BRAUN, M., VICAS, L., Determination of Oligoelements Content of Plant Material and Assessment of Bioactive Compounds from Calendula officinalis Lyophilized Extract, Rev. Chim. (Bucharest), 68, no. 8, 2017, p.1786.

17. COPOLOVICI, L., TIMIS, D., TASCHINA, M., COPOLOVICI, D., CIOCA, G., BUNGAU, S., Diclofenac Influence on Photosynthetic Parameters and Volatile Organic Compounds Emision from Phaseolus vulgaris L.Plants, Rev. Chim. (Bucharest), 68, no. 9, 2017, p.2076.

18.CEAUSESCU, V. E., RADOIAS, G., CADARIU, T., Odorante si aromatizante. Chimie, Tehnologie, Aplicatii, Ed. Tehnica, Bucuresti, 1988.

19. MOLDAVAN, Z., Metode de monitorizare a substantelor toxice. Note de curs si aplicatii, Ed. Universitatii din Bucuresti, 2012.

20. DAVID,V., MEDVEDOVICl, A., Metode de separare $@ i$ analiza cromatografica, editia a II-a, Ed. Universitatii din Bucuresti, 2008.

21.*** http://www.europeana.ro/dosare/mediu.htm.legislape.

22. XXX, GHIDUL SG, Criterii ecologice pentru produse din piele si blanuri, 2004.

23. ***http://www.triderma.ro. Produse chimice pentru argasirea si vopsirea blanurilor.

24. BALAU MANDRU, T.,NICULESCU, O., PRUNEANU, M., MAIER, V., Product with antistatic-antifelting effect for fur treatment, Patent OSIM $127298 / 2014$

25. NICULESCU, O., TONEA, R.A., TONEA, S, Product for biological protection and fragrance of furs and fur garment, Patent Aplication OSIM A/00395/2014.

26. NICULESCU, O., LECA, M., MOLDOVAN, Z., DESELNICU, D.C., Obtaining and characterizing a product with antifungal properties based on essential oils and natural waxes for finishing natural leathers, Rev. Chim. (Bucharest), 66, no. 11, 2015, p.1733.

27. NICULESCU, O., LECA, M., MOLDOVAN, Z., DESELNICU, D.C., Research on obtaining products for fragrance and biological protection of natural leathers and furs, Rev. Chim. (Bucharest), 66, no. 12, 2015, p. 1956

$\overline{\text { Manuscript received: } 14.09 .2018}$ 